\title{
POSSIBILITY OF DETERMINING ARGUMENTATION IN SOCIAL SCIENCE ARTICLES: THE CASE OF LATVIAN
}

\author{
Dzintra Lele-Rozentāle ${ }^{1}$, Diāna Laiveniece ${ }^{2}$, Agnese Dubova ${ }^{3}$, Baiba Egle ${ }^{4}$
}

\begin{abstract}
Argumentation is an essential part of the research process and its linguistic representation. Argumentation, as well as the formation of appropriate wording requires that the author is familiar with different types of argumentation and the experience with their use to substantiate one's thoughts and statements in a proper scientific way. Until now, argumentation as an object of linguistic research in scientific has been widely researched, but in the context of scientific articles in Latvian, it has not been studied at all.

This paper explores the possibilities of qualitative analysis of argumentation in order to develop a methodology for determining the presence of argumentation and further linguistic research on it (for example, classification of argumentation by strategy, structure, scope or expansion, etc.).

To achieve the intended goal, 20 social science articles (published from 2016-2018) in Latvian have been selected from the fields of political science, economics and business, education, and sociology. These articles were structurally different, 8 articles strictly adhered to IMRaD format, 6 articles partially followed it (mainly the discussion section was missing) while the remaining 6 articles completely ignored the IMRaD format. The selection of articles was done to accept or reject the initial hypothesis that the proportion of argumentation is directly related to the IMRaD structure of the articles.

To determine the argumentation, the same research methods that are used in computational linguistics are applied to qualitative research and manual text zone marking is used. The study was intended to obtain and test a universal methodological approach that could be used for future linguistic research in disciplines (mainly humanities and arts) where the IMRaD structure is not used.
\end{abstract}

UDC Classification: 81'33, DOI: https://doi.org/10.12955/pss.v2.225

Keywords: scientific language, argumentation, text zoning, article, social science

\section{Introduction}

Argumentation is a means of creating new knowledge and an integral part of scientific articles. The structure of a scientific article has traditionally been different in different disciplines and cultures Graefen \& Thielmann, 2007). Due to various external factors like high prestige of natural sciences and engineering, the role of English as a global language of science, the rapid expansion of international scientific contacts, strengthening and formalization of science policy infrastructure, the traditional text formation of scientific cultures is also changing.

In the first two decades of the 21st century, this process has significantly affected the sub-branches of science in Latvia. The influence of the factors mentioned in the publications of Latvian scientific articles can be observed in the widespread application of the IMRaD structure, not only in natural science and its related fields but also in social sciences and even in the humanities. In these disciplines and their subbranches, there is a relatively large diversity in terms of article macrostructure, which is often determined by external factors like publication conditions, and sub-branch traditions (Dubova, Egle, Proveja, 2020).

The topic for this article was determined for several reasons:

1) The study of argumentation in Latvian linguistics is much needed; it is also poorly understood in other disciplines. The only major study on argumentation in Latvian is Edmunds Apsalons' Logic of Language Use (Apsalons, 2011), which focuses on the use of argumentation in cultural studies and philosophy as an "Introduction to Elementary Logic and Scientific Argumentation". Linguistic research on the structure of argumentation and its types in scientific texts is still lacking, it is not taught in school and university programs, therefore argumentation skills are rather acquired in the long-term through practice unless they are based on certain research

\footnotetext{
${ }^{1}$ Liepaja University, Kurzeme Institute of Humanities, dzintral@venta.lv, https://orcid.org/0000-0003-31816929

2 Liepaja University, Kurzeme Institute of Humanities, diantra@ gmail.com, https://orcid.org/0000-0002-31072109

${ }^{3}$ Liepaja University, Kurzeme Institute of Humanities, agnesed@ venta.lv, https://orcid.org/0000-0002-74281824

${ }^{4}$ Liepaja University, Kurzeme Institute of Humanities, baiba.egle@ venta.lv, https://orcid.org/0000-0002-62077789
} 
socialization, that is, learning via experience, for example, study experience in other countries, international contacts, projects.

2) Argumentation in scientific articles is also considered to be the latest topic of research internationally. This conclusion stems from the diversity of research methodologies, which are not always complimentary. Roncoroni (2015), in their review of research methodology, emphasized the lowest efficiency of quantitative methods, which can be explained by the predetermination of research categories, which in turn means limited view and ontological reduction (Thielmann, 2009, cited from Roncoroni, 2015). The advantages of qualitative techniques are seen in the use of content analysis (ibid).

3) The third reason for conducting a pilot study on text structure-oriented argumentation is the assumption of the suitability of such argumentation for social sciences based on the previous two factors. According to the previous research, Latvian scientific articles in the field of social sciences form a heterogeneous picture, the texts have both, a traditional structure i.e. the main characteristics of the humanities (introduction, main part, conclusion) and IMRaD structure, sometimes modified (Egle \& Tomase, 2020). In IMRaD structure, introduction and discussion per definitionem is an important part of argumentation and serves as the starting point for the analysis of a study. The argumentations have also been found under the discussion section of the texts prepared in the traditional three-part format. By focusing on the explicit part of the text (in the structure of IMRaD) or the implicit part of the discussion, where certain sections of the argumentation of the article could be expected (see criteria below), it is possible to test the suitability of different methods for determining the argumentative structure of the text, including the compliance of the results of argument zoning used in computational linguistics with the results of qualitative research.

The selection of text was done with the intention to accept or reject the initial hypothesis that the proportion of argumentation is directly related to the texts of the IMRaD structure.

The aim of this paper is to look at the possibilities qualitative analysis of argumentation in the chosen texts to develop a methodology for determining the presence of argumentation and further linguistic research on it (for example, classification of argumentation by strategy, structure, scope, or expansion, etc.).

\section{Material and methods}

20 social science articles published in Latvian, from the annual collection of articles of one university from 2015 to 2018 (see bibliography for the full reference, source coded as RSU1, RSU2, RSU3 and RSU4) have been selected for the study.

Structure wise different articles have been selected for the research:

1) Eight articles in the study are strictly based on the IMRaD format: All the articles have an introduction, a separate section is dedicated to the objectives of the study, followed by a description of the material and methods used, presentation of results, a discussion part, and conclusions.

2) Six articles in the study partially complied with the IMRaD structure: Most of these articles lack the discussion, which is one of the most important components of an article, where argumentation could be established.

3) In the other six articles the IMRaD format was not followed: These articles were based on the topic and their content did not follow strict IMRaD structuring.

The selection of articles was done to accept or reject the initial hypothesis that the proportion of argumentation is directly related to the texts of the IMRaD structure.

Even the selected articles within the same sub-category of social science were not homogeneous in terms of their IMRaD structure:

- Only three out of ten articles from political science complied with the IMRaD structure, five partially complied with it and two did not comply with it;

- Five articles were from the field of economics and business and the IMRaD structure was not observed in any of these articles, it was partially observed in one article, in other cases, the article was structured as per the content; 
- All the four articles from education sciences and one from sociology and social work have consistently followed the IMRaD structure.

The structure of 14 social science articles under study reveals variations in different sections of the IMRaD structure (see Table 1 below).

\begin{tabular}{|c|c|c|c|c|c|c|c|c|}
\hline & $\begin{array}{c}\text { Sources } \\
\text { (articles) }\end{array}$ & I & Aim & $\mathbf{M}$ & $\mathbf{R}$ & D & Conclusions & Other sections \\
\hline 1. & $\begin{array}{l}\text { Economics and } \\
\text { business 2015a }\end{array}$ & $\mathrm{X}$ & \multicolumn{2}{|c|}{$\begin{array}{c}\mathrm{X} \\
\text { (Aim and Methods) }\end{array}$} & $\mathrm{x}$ & & $\mathrm{X}$ & \\
\hline 2. & Sociology 2015 & $X$ & $\mathrm{X}$ & $\mathrm{X}$ & \multicolumn{2}{|c|}{$\begin{array}{c}\mathrm{X} \\
\text { (Results and } \\
\text { Discussion) }\end{array}$} & $\mathrm{X}$ & \\
\hline 3. & $\begin{array}{l}\text { Political science } \\
\text { 2015a }\end{array}$ & $\mathrm{X}$ & $\mathrm{X}$ & $X$ & $\mathrm{x}$ & & $\mathrm{X}$ & \\
\hline 4. & $\begin{array}{l}\text { Political science } \\
\text { 2015b }\end{array}$ & $X$ & $\mathrm{X}$ & $X$ & \multicolumn{2}{|c|}{$\begin{array}{c}\mathrm{X} \\
\text { (Results and } \\
\text { Discussion) }\end{array}$} & $\mathrm{X}$ & Tasks \\
\hline 5. & Education 2016a & $\mathrm{X}$ & $\mathrm{X}$ & $\mathrm{X}$ & \multicolumn{2}{|c|}{$\begin{array}{c}\mathrm{X} \\
\text { (Results and } \\
\text { Discussion) } \\
\end{array}$} & $\mathrm{X}$ & $\begin{array}{l}\text { Theoretical justification, } \\
\text { Suggestions }\end{array}$ \\
\hline 6. & Education 2016b & $\mathrm{X}$ & $\mathrm{X}$ & $\begin{array}{c}\mathrm{X} \\
\text { (Methods) }\end{array}$ & $\mathrm{x}$ & $\mathrm{x}$ & $\mathrm{X}$ & \\
\hline 7. & Education 2016c & $\mathrm{X}$ & $\mathrm{X}$ & $\begin{array}{c}\mathrm{X} \\
\text { (Methods) }\end{array}$ & & $\mathrm{x}$ & $\mathrm{X}$ & Theoretical justification \\
\hline 8. & Education 2016d & $X$ & $\mathrm{X}$ & $\mathrm{X}$ & $\mathrm{x}$ & $\mathrm{x}$ & $\mathrm{X}$ & \\
\hline 9. & $\begin{array}{l}\text { Political science } \\
2017\end{array}$ & $X$ & & & & $\mathrm{x}$ & $\mathrm{X}$ & \\
\hline 10. & $\begin{array}{l}\text { Political science } \\
2018 \mathrm{a}\end{array}$ & \multicolumn{3}{|c|}{$\begin{array}{c}\mathrm{X} \\
\text { (Introduction, Aim and } \\
\text { Methods) }\end{array}$} & & $\mathrm{x}$ & $\begin{array}{c}\mathrm{X} \\
\text { (Results and } \\
\text { Conclusions) } \\
\end{array}$ & \\
\hline 11. & $\begin{array}{l}\text { Political science } \\
2018 \text { b }\end{array}$ & $\mathrm{X}$ & $\mathrm{x}$ & $\mathrm{X}$ & \multicolumn{2}{|c|}{$\begin{array}{c}\mathrm{X} \\
\text { (Results and } \\
\text { Discussion) }\end{array}$} & $\mathrm{X}$ & \\
\hline 12. & $\begin{array}{l}\text { Political science } \\
2018 \mathrm{c}\end{array}$ & $\mathrm{X}$ & $\mathrm{X}$ & & $\mathrm{x}$ & & $\mathrm{X}$ & \\
\hline 13. & $\begin{array}{l}\text { Political science } \\
2018 \mathrm{~d}\end{array}$ & $\mathrm{X}$ & \multicolumn{2}{|c|}{$\begin{array}{c}\text { (Aim, Materials and } \\
\text { Methods) }\end{array}$} & & & $\mathrm{X}$ & \\
\hline 14. & $\begin{array}{l}\text { Political science } \\
2018 \mathrm{e}\end{array}$ & $\mathrm{X}$ & \multicolumn{2}{|c|}{ (Aim and Method) } & $\mathrm{x}$ & & $X$ & \\
\hline \multicolumn{9}{|c|}{ Source: Authors } \\
\hline
\end{tabular}

It has been observed that in some articles two or even three sections were merged under one title; certain sections from the articles were excluded; the discussion section or the combined section of the discussion and results section was commonly avoided and in some articles, non IMRaD sections were added.

These variations cannot be explained unambiguously, so it is possible to list several possible reasons why the authors modified the IMRaD structure in their articles as:

(1) Lack of experience of authors in writing articles using the IMRaD structure.

(2) Lack of knowledge about the content that should be written directly under each section of the text, for example, what should be included in the discussion section;

(3) Incompatibility of IMRaD with the topic of the article and the author's intention;

(4) Publication requirement to structure the article in IMRaD format.

Due to the small sample size of research articles and the uneven representation of articles from different sub-disciplines of social sciences (political science (50\%), economics and business (25\%), educational sciences $(20 \%)$, sociology and social work (5\%)), the results of this study cannot yet be generalized.

Argumentation can be viewed in two ways: (1) As persuasive, the origin of which leads to ancient rhetoric; (2) As exploratory, which has evolved with the progress of science and which means the further development of knowledge, thus the transformation of the clarified unknown into the known (Ehlich, 2014).

Swales (1990), analyzed the results of the previous research in the literature review, and points to the close relationship between the research question(s) in the introductory part and the eight moves 
commonly/frequently found in the discussion: Background information, statement of results, (un)expected outcome, reference to previous research, explanation, , deduction and hypothesis and recommendations. These moves partially overlap with the method of annotation of zones developed in computational linguistics.

Research methods were selected as per the aim of the article. The theoretical base of the research is formulated on the basis of Teufel's (1999) monograph on the zoning of scientific text argumentation in seven categories. Thus, the methodological basis of the research is Argumentative Zoning. According to zoning theory (Teufel 1999; Teufel et al., 1999), each sentence of a scientific article (in some cases a paragraph) represents one of seven areas of argumentation:

BKG: General scientific background (yellow),

OTH: Neutral descriptions of other people's work (orange),

OWN: Neutral descriptions of the own, new work (blue),

AIM: Statements of the particular aim of the current paper (pink),

TXT: Statements of textual organization of the current paper (red),

CTR: Contrastive or comparative statements about other work; explicit mention of weaknesses of other work (green),

BAS: Statements that own work is based on other work (purple).

Each area is marked with its specified colour, thus clearly distinguishing the generalization of the content of the scientific text. In the zoning process, it is possible to identify and mark argument statements in the text.

Argumentation zoning has advantages over cataloguing, as it is more transparent and allows the types of arguments to be fixed during zoning, thus opening the possibility for further linguistic analysis of the text. The 7 selected zoning fields partially cover the criteria used in qualitative research, which are designed to capture an in-depth study of the structure of the argumentation of a scientific text and its forms of linguistic expression. While studying argumentation in the composition (Italian and German scientific articles) Roncoroni (2015) focused on 6 dimensions: position and thesis of the question, the structure of argumentation, arguments, cognitive aspects, critique anticipation, argumentative style. Her catalogue includes 10 types of arguments (examples, comparison, facts/data, authority explicit, authority implicit, functional justification/teleological argument, functional justification as a no-content convention, shared knowledge, societal mechanisms, and reference to normality) allowed a detailed analysis of texts that is not foreseen in this study. Combining these two approaches and their benefits of visibility and detailing could make it possible for future research to develop a research process for the argumentation of scientific articles based on the principle of gradation.

\section{Results}

By reviewing the division of articles into zones and their respective content, it is found that the facts of the argument are more frequent in the OWN, CTR and BAS zones, as the facts of the study itself (OWN) must be proved and the evidence requires argumentation; while criticizing other authors' studies (CTR), the criticism must be substantiated; and while linking other author's studies to their own study (BAS) requires an argument to justify this link.

Therefore, we prepared an overview in Table 2, distinguishing all the articles based on IMRaD structure, the first eight items in the table represent articles with IMRaD structure, the next six items represent articles that followed a partial IMRaD structure, and the last six items in the table represent articles which do not follow IMRaD structure.

While zoning articles, it is quite difficult to define the boundaries between OTH and BAS or between BKG and OTH. It can be assumed that OTH is when the text implicitly (through references only) refers to another study, while BAS is when there is an explicit reference to another author's findings in a particular study, by citing the author or the source. The BKG is most often given without any reference, which in some cases makes it difficult to distinguish it from the OWN. If the text does not clearly indicate the boundaries of the paraphrase in the text, there are doubts about the separation of the OWN zone from OTH or BKG.

\begin{tabular}{|l|l|l|l|l|l|l|l|l|l|}
\hline \multicolumn{1}{|l|}{ Table 2: IMRaD specific types uses in the articles } \\
\hline & total & AIM & TXT & BKG & OTH & OWN & CTR & BAS \\
\hline 1. & Sociology 2015 & 57 & 1 & 3 & 2 & 13 & 24 & 0 & 14 \\
\hline
\end{tabular}




\begin{tabular}{|l|l|l|l|l|l|l|l|l|l|}
\hline 2. & Political science 2015b & 20 & 1 & 0 & 1 & 3 & 9 & 1 & 5 \\
\hline 3. & Education 2016a & 50 & 1 & 1 & 9 & 13 & 16 & 1 & 9 \\
\hline 4. & Education 2016b & 38 & 1 & 0 & 5 & 16 & 16 & 0 & 0 \\
\hline 5. & Education 2016c & 25 & 1 & 0 & 1 & 9 & 14 & 0 & 0 \\
\hline 6. & Political science 2018a & 35 & 1 & 0 & 8 & 10 & 6 & 0 & 0 \\
\hline 7. & Political science 2018b & 35 & 3 & 2 & 12 & 6 & 8 & 3 & 1 \\
\hline 8. & Education 2016d & 28 & 1 & 0 & 3 & 8 & 14 & 4 & 0 \\
\hline 9. & Economics, business 2015a & 32 & 2 & 1 & 13 & 6 & 10 & 0 & 0 \\
\hline 10. & Political science 2015a & 49 & 2 & 1 & 14 & 11 & 16 & 2 & 3 \\
\hline 11. & Political science 2017a & 31 & 2 & 0 & 2 & 8 & 10 & 4 & 5 \\
\hline 12. & Political science 2018c & 15 & 1 & 0 & 4 & 1 & 8 & 0 & 1 \\
\hline 13. & Political science 2018d & 9 & 1 & 0 & 1 & 3 & 4 & 0 & 0 \\
\hline 14. & Political science 2018e & 25 & 1 & 1 & 11 & 3 & 9 & 0 & 0 \\
\hline 15. & Economics, business 2017a & 70 & 1 & 1 & 11 & 24 & 17 & 14 & 2 \\
\hline 16. & Economics, business 2017b & 46 & 1 & 1 & 10 & 6 & 21 & 0 & 7 \\
\hline 17. & Political science 2017b & 73 & 1 & 0 & 7 & 25 & 33 & 1 & 6 \\
\hline 18. & Economics, business 2018 & 44 & 1 & 0 & 6 & 2 & 18 & 1 & 16 \\
\hline 19. & Political science 2017c & 35 & 1 & 0 & 1 & 8 & 23 & 2 & 0 \\
\hline 20. & Economics, business 2017c & 18 & 1 & 0 & 9 & 0 & 8 & 0 & 0 \\
\hline Source: Authors & & & & & & \\
\hline
\end{tabular}

The most easily defined sections in an article are AIM, TXT, and CTR, these are also the least represented. As the research highlights, the authors of social science articles usually set the goal of their article, sometimes they refer it during their research, quite rarely (TXT is found in 8 articles out of 20) they focus on the description of the text structure, and only 10 out of 20 articles used CTR as authors generally avoid criticizing other's research.

By examining the articles according to the IMRaD structure in sociology, political science and education in terms of the zoning described above, it is found that majority of the articles, $37.1 \%$, are based on the results of their own research (OWN), 27.1\% articles described the findings of other authors studies (OTH) of other authors. A relatively small percentage i.e. only $10 \%$ articles linked their study to the findings of others (BAS), while the criticism of other authors is the least common in IMRaD structured articles $(3.1 \%)$. Criticisms of other studies can often be found under the materials and methods section and in an article it was found in the introduction. There are even fewer articles based on the references to text structure (TXT), only $2 \%$.

Six of the articles under study (five from political science and one from economics and business) show a partial structure of IMRaD. The discussion part is mostly missing in five cases. Most of the zoning is occupied by OWN (35.4\%), followed by BKG (2.79\%) and OTH (19.9\%). Target and structure indications accounted for a small share of the entire text, $5.6 \%$ and $1.9 \%$ respectively. The CTR relevant for argumentation is $3.7 \%$ and BAS 5.6\%. Compared to articles completely following IMRaD format, the share of CTR is slightly higher, but that of BAS is smaller.

Zoning six articles in political science and economics that did not have IMRaD structure, OWN, CTR and BAS sections together accounted for 59\% of the total articles under study. Additionally, the share of CTR in such articles is higher $(6.3 \%)$ than that in articles that are fully (3.1\%) or partially complied (3.7\%) with the IMRaD structure. Commonly missing area is an indication of the structure of the article (found in only two of the six articles), two articles did not have criticism of other studies (CTR), two have no other studies linking to their article (BAS) and one has no comparison with other studies (OTH). One of the types of argumentation in scientific works is closely related to comparison and indication of critical remarks. The study shows that half of the articles studied have a comparison with other studies and explicitly indicated the shortcomings and deficiencies in the previous studies. Similar thoughts, similar studies, are mentioned and described for the comparison statement etc., as well as differences from other studies are also documented. The expression of similarity can be identified by signal words like similarly (līdzīgi), convenes (sasaucas), identical (identiski), expressions of differences - differs from (atšķiras no), differs in that (atškiras ar to). To point out the shortcomings of previous studies, connectors are used like although (kaut gan), even though (lai arī), though (lai gan), however (tomēr) etc. Criticisms of previous studies are often explicitly pointed to the problems such as main problem, 
basic problem etc., as well as a substantiated denial or recommendations as to when or under what conditions the study in question should be used. Recommendations are often expressed as need or desire. The linguistic formulations found in the criticism part make it necessary to create a catalogue of arguments and their linguistic formulations to be able to carry out further research of argumentation in Latvian, its types and linguistic expression in Latvian scientific texts.

\section{Discussion}

Text zoning, a method used in computational linguistics shows that it can also be used for qualitative argumentative research in linguistics. True, this method is quite complicated to use, as it requires zoning practitioners to understand the research topic. The role of the human factor in the interpretation of the argumentation in the text and their past experience is evidenced by the problems described in computer linguistic publications related to the person who annotates the text also known as intercoder, thereby narrowing the reliability base of the analysis (Teufel, 1999; Teufel et al. 1999; Teufel et al., 2009; Kirschner et al., 2015; Roncoroni, 2015). To this problem, annotator training is often arranged before the study. In this study, the analysis was done by the authors of the article including the discussion, and interpretation of the zoning results.

The application of this method is limited by the time required for zoning a single text, as it is a manual operation and the processing of research material cannot be applied to a large body of text, therefore the obtained results may not be immediately generalizable. However, by increasing the number of scientific materials and the range of scientific articles for analysis, as far as possible, the obtained results can show trends in the application of argumentation in scientific articles, which would allow drawing conclusions in several directions like:

1) The overall correlation with the proportion of arguments in individual disciplines and / or subdisciplines;

2) Facts about the structure of the argument and the number of most frequently identified components;

3) Facts about the most frequently established argumentative relations;

4) The connection of the argumentation with certain areas of the text;

5) The connection between the reasoning and the structure of the text, namely IMRaD usability;

6) Linguistic means, which are more often used for argumentation.

As mentioned above, the discussion part resonates with the introduction, which also develops argumentation, because the new knowledge acquired in the discussion should be related to the existing knowledge and these results should be discussed (Graefen, Thielmann 2007). Thus, the obtained results are 'compatible' with previous research and/or expected results arising from the hypothesis or research question. Its discussion starts with matching the results with the established literature and to review their general significance (Swales, 1990). The following criteria are used for the analysis of the discussion: (1) summary of main results, evaluation, etc.; (2) linking the results with previous research, literature, research limitations; (3) generalization of results: link to a goal or hypothesis, unanswered questions, research perspective (PLOS, n.d.).

The analysis of the selected articles in the study shows that the main results are summarized under the discussion section, sometimes a link with the established goal is highlighted, which is not always explicitly stated. There is no link between the results and previous studies. Therefore, it is necessary to pay attention not only to the discussion part, but also to the final part of the scientific article, to identify the OWN, CTR and BAS areas and analyze the reasoning in them.

\section{Conclusions}

There is no correlation between the IMRaD structure and the proportion of factual arguments. It can be assumed that the proportion of factual arguments depends on the purpose of the article (i.e., the author's views on the need for argumentation) and the author's experience. Absence of argumentation skills being taught in schools and universities in Latvia may also be responsible for that. This could explain the absence of discussion section in a number of texts based on IMRaD structure, as well as the low proportion of CTR and BAS. In this context, the hypothesis of the culture-specific and science subbranch-specific nature of criticism in scientific texts should be tested.

Zoning as such does not directly affect the detection of an argument, but it makes the text more visible by reading more attentively and thus more easily noticing the facts of the argument. The developed 
theory (Teufel, 1999; Teufel et al., 1999) with seven zones does not cover all possible substantive aspects of the scientific text, for example, it does not refer to the description of the study itself, not the text organization, does not refer to example material, but arguments.

In future studies, while analyzing the IMRaD structured texts, the focus should be on the discussion section, assuming that the OWN, CTR and BAS areas, where argumentation is needed, could play a significant role.

\section{References}

Apsalons, Edmunds (2011). Valodas lietojuma logika. Ievads elementārajā logikā un zinātniskajā argumentācijā. Kultūras zinätne un filozofija. [Logic of language use. Introduction to elementary logic and scientific argumentation. Culturology and philosophy.] Rīga: Zvaigzne ABC.

Dubova, Agnese; Egle, Baiba; Proveja, Egita (2020). IMRAD usage in Latvian language research papers. Proceedings of CBU in Social Sciences 1, 33-39. DOI: https://doi.org/10.12955/pss.v1.42

Egle, Baiba, Tomase, Kristīne (2020). Zinātniskā raksta specifika sociālajās zinātnēs. [Specifics of the scientific article in the social sciences]. Vārds un tā pētīšanas aspekti: rakstu krājums, 24 (1/2). Liepāja: LiePA, 280-288. DOI:

https://dom.lndb.lv/data/obj/879147.html

Ehlich, Konrad. (2014). Argumentieren als sprachliche Ressource des diskursiven Lernens. [Argumentation as a language resource of discursive learning]. Antonie Hornung, Gabriella Carobbio, Daniela Sorrentino (eds.). Diskursive und textuelle Strukturen in der Hochschuldidaktik. Deutsch und Italienisch im Vergleich. (Sprach-Vermittlungen, Vol. 12). Münster, New York: Waxmann, 41-54.

Graefen, Gabriele, Thielmann, Winfried. (2007). Der wissenschaftliche Artikel. [The scientific article]. Peter Auer, Harald Baßler. Reden und Schreiben in der Wissenschaft. Frankfurt, New York: Campus Verlag, 31-97.

Kirschner, Christian, Eckle-Kohler, Judith; Gurevych, Iryna. (2015). Linking the Thoughts. Analysis of Argumentation Structures in Scientific Publications. Proceedings of the 2nd Workshop on Argumentation Mining, 1-11, Denver, Colorado, June 4. Association for Computational Linguistics.

PLOS. (n.d.). How to Write Discussions and Conclusions. Retrieved 31/04/2021, from https://plos.org/resource/how-to-writeconclusions

RSU1 - Rīgas Stradiṇa universitāte. (2015). Zinātniskie raksti: 2014. gada sociālo zinātnu nozares pētnieciskā darba publikācijas. Ekonomika. Komunikācija. Politika. Sociologija. Sociālā politika un sociālais darbs. Tiesības.[Scientific articles; Social science research publications 2014. Economics. Communication. Politics. Sociology, Social Politics and Social Work.] Rīga: RSU.

RSU2 - Rīgas Stradiṇa universitāte. (2016). Zinātniskie raksti: 2015. gada sociālo zinātnuu nozares pētnieciskā darba publikācijas. Pedagogija. Tiesības. [Scientific articles; Social science research publications 2015. Pedagogy. Law]. Rīga: RSU.

RSU3 - Rīgas Stradiṇa universitāte. (2017). Zinātniskie raksti: 2016. gada sociālo zinātnu nozares pētnieciskā darba publikācijas. Politika. [Scientific articles; Social science research publications 2016. Politics.]. Rīga: RSU.

RSU4 - Rīgas Stradiņa universitāte. (2018). Zinātniskie raksti: 2017. gada sociālo zinātņu nozares pētnieciskā darba publikācijas. Politika. Tiesības. [Scientific articles; Social science research publications 2017. Politics. Law.]. Rīga: RSU. Roncoroni, Tiziana. (2015). Argumentative Strategien in deutschen und italienischen wissenschaftlichen Artikeln. Am Beispiel der Soziologie und der Sprachwissenschaft. [Argumentative strategies in German and Italian scientific articles. Based on Sociology and Linguistics]. (Variolingua. Nonstandard - Standard - Substandard, Vol. 47). Frankfurt am Main: Peter Lang.

Swales, John M. (1990). Genre Analysis. English in academic and research settings. (The Cambridge applied linguistics series). Cambridge, New York, Port Chester, Melbourne, Sydney: Cambridge University Press.

Teufel, Simone. (1999). Argumentative Zoning: Information Extraction from Scientific Text. PhD, University of Edinburgh. Teufel, Simone, Carletta, Jean, Moens, Marc. (1999). An annotation scheme for discourse-level argumentation in research articles. Proceedings of the Ninth EACL, 110-117.

Teufel, Simone, Siddharthan, Advaith, Batchelor, Colin. (2009). Towards Discipline-Independent Argumentative Zoning: Evidence from Chemistry and Computational Linguistics. Proceedings of the 2009 Conference on Empirical Methods in Natural Language Processing, 1493-1502, Singapore, 6-7 August. 2009 ACL and AFNLP. 